in the rind of the cane, which occur commonly during the summer months. It has been determined that this normal splitting is more extensive in varieties showing higher susceptibility to midge attack.

The rind tends to peel back from these splits, and under it the colonies of larvæ become established and feed locally on the young periderm tissue for about fourteen days, causing the discoloration and death of small patches of cells averaging approximately 2 sq. cm. in area. When fully fed, the larvæ leave the cane to pupate in the soil, and a few weeks later fungal fructifications are commonly found on the damaged areas, but not on the surrounding healthy tissue. Tissue exposed by splits which have not been invaded by midge tends to harden and is not attacked by fungi. It would thus seem that the activities of the midge produce a substrate favourable for the establishment of fungal wound parasites.

It is now known that in addition to $L$. coniothyrium, a species of Fusarium culmorum and Didymella applanata (the cause of spur blight in raspberries) similarly enter the cane through midge-feeding lesions, causing severe damage. These two additional fungi are found more commonly than $L$. coniothyrium during the summer months.

Tests so far carried out suggest that the midge does not introduce fungal spores into the splits, but rather that they are air- or water-borne.

One of us (R. S. P.) wishes to make acknowledg. ment to the Agricultural Research Council, which has financed the entomological side of this investigation.

East Malling Research Station,

R. S. PtTCher

P. C. R. WEBB

Nr. Maidstone, Kent. Oct. 12.

${ }^{1}$ Theobald, F. V., Min. of Agric. Monthly Summaries of Insect Pests of Crops for 1921 (not published).

'Harris, R. V., Rept. E. Malling Res. Stat. for 1929, 68 (1930).

'Fox-Wilson, G., and Green, D. E., J. Roy. Hort. Soc., 69, 79 (1944).

- Barnes, H. F., J. Roy. Hort. Soc., 69, 370 (1944).

\section{Biological Oxidation of Manganous Sulphate in Soils}

F. C. GerRetsen ${ }^{1}$ demonstrated the biological oxidation of manganous sulphate in soils. G. W. Leeper and R. J. Swaby ${ }^{2}$ confirmed this. A preliminary report is made here of investigations carried out to find the micro-organisms involved in the process.

Gerretsen isolated what he termed manganeseoxidizing bacteria on a mineral-salts medium containing calcium citrate and manganous sulphate. We have isolated on this medium a few organisms which oxidize the manganese. Those identified belong to the genera Pseudomonas, Serratia and Aerobacter. None of these organisms when added alone to a sterile soil of $p \mathbf{H} 6 \cdot 8$ will reproduce the manganese oxide rings described by Leeper and $\mathrm{Swaby}^{2}$; mixtures of these organisms will not.

Gerretsen's medium was discarded, and a medium prepared from a soil of $p H \mathbf{H} .8$ which exhibits manganese deficiency for plants was used. The medium was prepared by shaking a 1/20 mixture of the soil and water and decanting the suspended material. To this suspension, agar and hydrated manganous sulphate were added to give final concentrations of 2 and 0.005 per cent respectively. The medium was autoclaved at $15 \mathrm{lb}$. for $20 \mathrm{~min}$. on three consecutive days.

Material sown from the oxide ring $^{2}$ to this medium showed oxidation of the manganese in the confluent growth, but no single colonies taken from these plates could oxidize manganese. Pure cultures of single colonies were isolated and then mixed in pairs. Certain pairs could oxidize the manganese in this medium. These pairs, when inoculated into sterile soil agar $(p H 6 \cdot 8)$, reproduced the type of oxide rings found with the unsterilized soil; singly, the cultures did not. The pairs will oxidize the manganese in filtered water soil extracts plus 0.005 per cent manganous sulphates in 48 hours. The oxidation occurred at a $p H$ below $7 \cdot 0$ in this extract.

The investigation is proceeding along two lines. One is the study of the process by which the paired bacteria oxidize the manganese. The other is to determine the significance of these organisms in rendering manganese unavailable to plants.

The possibility of the existence of other microorganisms involved in the oxidation of manganese has not been overlooked.

V. B. D. SKrerman

S. M. BROMFIELD

School of Bacteriology,

University of Melbourne, Melbourne, N.3.

${ }^{1}$ Gerretsen, F. C., Verslag Landbouwk Onderzoek, No. 42 A, 57 (1936). ${ }^{2}$ Leeper, G. W., and Swaby, R. J., Soil Science, 49, No. 3, 163 (1940).

\section{A Narwhal in the Thames Estuary}

THE recent stranding of a narwhal (Monodon monoceros) at Rainham, Essex, is a record of considerable interest. This species is usually limited to Arctic waters, although it occasionally penetrates into the North Sea. The infrequency of its occurrence off the British coast may be gauged by the fact that since 1588, when one was found on the coast of Norfolk, as recorded by Purchas', only three other instances until the present one are known. These were one on the Isle of May in the Firth of Forth, in June 1648; one near Boston, Lincolnshire, in February 1800; and one in the Sound of Weesdale, Shetland, in September 1808.

The Rainham animal, which stranded on February 17,1949 , was a female $12 \mathrm{ft} .11 \mathrm{in}$. in length. It was photographed several times after having been hoisted into the air by a riverside crane, and the pictures of it make identification of species certain : the general body-form, mottled pigmentation, characteristic shape of the flippers and tail flukes, and the absence of a dorsal fin all point to the animal having been a narwhal. There was no tusk projecting from the snout such as is found in the male.

Unfortunately, first information about the Rainham narwhal was not obtained until it was too late to inspect the carcase; it sank while being towed from the place where it first stranded.

$$
\text { F. C. Fraser }
$$

Department of Zoology,

British Museum (Natural History), London, S.W.7.

1 "Purchas his Pilgrimage", 621 (London, 1613). 